\title{
Hiawatha 撞击作用是新仙女木事件的诱因吗?
}

\author{
肖龙 1,2
}

1. 中国地质大学(武汉)地球科学学院, 武汉 430074;

2. 中国科学院比较行星学卓越创新中心, 合肥 230026

E-mail: longxiao@cug.edu.cn

Science 公布的 2018 年十大科学突破之一, 是在地球北 极圈格陵兰岛西北部的 Hiawatha 冰川下, 发现了一个直径 约 $31 \mathrm{~km}$ 的大型撞击坑 ${ }^{[1]}$ (https://vis.sciencemag.org/breakthrough2018/finalists/\#cell-development). 该项成果由丹麦 哥本哈根大学 Kjær 为首的国际科学家团队 ${ }^{[1]}$ 完成, 于 2018 年 11 月发表在 Science Advances 上.

该团队利用 1997 2016 年间的机载雷达测声探测资 料, 对格陵兰岛冰盖区域冰层和冰下地形进行研究时, 在 西北部 Hiawatha 冰层之下发现了一个圆形洼陷区域, 直径 约 $31 \mathrm{~km}$, 深约 $800 \mathrm{~m}$, 中间有个微小的隆起以及零星、类 似中央峰环的痕迹. 这和大型复杂撞击坑的形貌特征较为 吻合, 由此提出这可能是一个被冰川掩盖的撞击坑. 随后, 该团队开展了实地地质调查, 并在圆形洼陷北部冰河沉积 物中找到了冲击变质证据, 即发现了石英的高压变形现 象一发育面状变形构造这一诊断性证据 ${ }^{[1 \sim 3]}$. 作者还在 沉积物样品中发现含量较高的镍、钴、铂系元素等亲铁元 素, 从而认为这是一个铁陨石或铁质小行星碎片撞击而形 成的复杂撞击坑. 尽管缺乏其他撞击作用的证据, 如发育 在靶岩上的震裂雉、撞击溅射物和撞击形成的重力异常等, 但文章根据其形貌和高压冲击变质矿物等证据, 将这个圆 形洼陷解释为撞击作用所致是合理的.

这一发现, 使之成为第一个冰层之下被发现的撞击坑, 是地球上 25 个最大的撞击坑之一, 而且是这类大型撞击 坑中初始形态保存最好的. 因此可以用于研究地球撞击坑 的形成机制, 对于开展类地天体撞击作用的对比研究, 也 有重要的意义.

那么, 需要多大的陨石撞击地球, 才能形成这么大的 撞击坑呢? 该团队认为, 如果当时这一带没有冰层覆盖, 那么这个撞击体的直径约为 $1500 \mathrm{~m}$, 以每秒十几千米的高 速撞击地表后, 会首先产生一个直径约 $20 \mathrm{~km}$, 深约 $7 \mathrm{~km}$ 的瞬时坑. 随后, 瞬时坑会由于重力平衡作用, 迅速坡塌, 形成这个直径约 $31 \mathrm{~km}$, 深约 $800 \mathrm{~m}$, 有中央峰的复杂撞击 坑. 如果该地当时已经被冰层覆盖, 就应该是一个直径更 大的小行星撞击, 才能形成这么大的撞击坑. 有关这次撞 击事件发生的时间, 作者综合多种地形地貌及宏观地质判 别标志, 认为最有可能形成于更新世. 同时, 作者认为这 次大撞击会释放出巨大的能量, 可能对北半球甚至全球

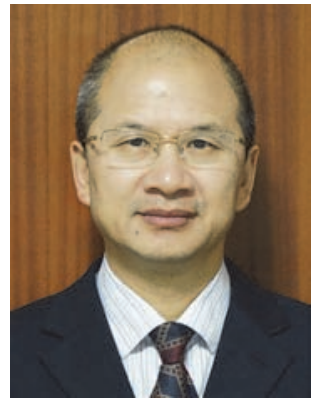

省龙岩石学及行星地质学家, 现任中国地质大学(武汉)教授、澳 门科技大学特聘教授. 长期从事岩 石学和行星地质学教学和科研工 作．在类地行星火山作用及表面地 质过程、火星与地球的对比研究、 月球地质研究、地幔柱岩浆作用、 火成岩成因等方面, 取得了多项重 要成果.

环境造成巨大的影响 ${ }^{[1]}$.

大型撞击作用对地球生态环境造成破坏性影响是公 众和科学家共同关注的重大问题之一. 例如, 地球历史上 的 5 次生物大灭绝事件, 以及更多小规模的生物快速灭绝 事件, 都被怀疑过可能与外星体的撞击有关. 尽管目前较 为公认的只有第五次生物大灭绝事件最有可能是外星体 撞击导致的, 即 6600 万年前导致了恐龙灭绝的希克苏鲁 伯(Chicxulub)撞击事件. 这次撞击事件在墨西哥湾形成了 一个直径约 $200 \mathrm{~km}$ 的撞击坑. Kjær 等人 ${ }^{[1]}$ 新发现的 Hiawatha 撞击事件发生在北极圈, 可能与地球历史上导致 末次冰期后的新仙女木生态环境变化事件有关, 而受到高 度关注. 这可能也是被 Science 列为 2018 年度十大科学突 破之一的原因.

第四纪地质研究表明, 自冰河世纪结束以后, 地球气 候于大约 17000 年前开始变暖, 气温逐渐回升. 两极、北 美和北欧的冰川开始消融, 海平面逐渐上升, 渤海、黄海、 挪威海的草原被水淹没. 到了 13000 年前, 北美和北欧的 冰雪已经融化了相当大一部分, 南北半球春暖花开, 一片 繁荣景象. 但是, 就在这时(大约在 12640 年前), 气温又骤 然下降了, 世界各地转人严寒, 两极和阿尔卑斯、青藏高 原等地的冰盖扩张, 许多本来迁移到高纬度地区的动植物 大批死亡, 包括长毛猛犸象和其他生物的灭绝，也让美国 印第安克洛维斯人从此消失. 这一次降温很突然, 降温幅 度也很大, 直到 11500 年前, 气温才又突然回升. 这就是 地球历史上著名的新仙女木事件 ${ }^{[4]}$ ，时间为距今 12900 11500 年期间 ${ }^{[5]}$. 
新仙女木事件发生得非常突然, 至今仍未有足够的证 据阐明其产生的原因. 有关仙女木事件的触发机制的主要 观点包括融冰淡水驱动假说、慧星撞击假说、气候自然变化 假说、大气驱动假说、低纬驱动假说和太阳活动变化等 ${ }^{[6]}$.

作为比较流行的假说之一, 彗星撞击假说首先是由 Firestone 等人 ${ }^{[7]}$ 于 2007 年提出的. Firestone 等人 ${ }^{[7]}$ 在北美 一套形成于 12900 年的黑色碳质岩层之下, 发现了已经灭 绝的更新世巨型动物的原地骨骼, 以及克洛维斯人的工具 组合, 其成果发表在 Proc Natl Acad Sci USA (美国科学院 院刊)上. 在这篇论文中, 作者将克洛维斯期的多处高铱沉 积、磁性颗粒、磁性微球、木炭、碳小球、含纳米金刚石 的玻璃碳等现象, 归结为一个或多个大的、低密度的天体 (如碳质球粒陨石、彗星)在北美北部上空爆炸, 部分破坏了 劳伦泰德冰原的稳定, 并引发了新仙女木期的降温. 冲击 波、热脉冲和与事件相关的环境影响(例如, 大规模的生物 质燃烧和食物短缺)促成了北美古美洲人在更新世末期的 大灭绝和适应性转变.

这一观点一经提出, 就被高度关注且备受争议. 支持 者继续补充了多个与撞击作用有关的证据, 包括同时期形 成的纳米钻石 ${ }^{[8]}$ 、冲击变质石英、焦石英、炉渣状物质等 ${ }^{[9]}$. 而反对者也提出了很多质疑, 否认撞击事件导致了新仙女 木事件的发生 ${ }^{[10 \sim 16]}$. 例如, 所谓的碳质球体可能是真菌菌 核, 并且在加州 Channel 岛更新世-全新世地层中普遍存 在 $^{[12]}$, 先前被报道的纳米钻石也没有被再次找到 ${ }^{[14]}$, 边界 层中所谓的高浓度铱元素异常没有得到确认 ${ }^{[15]}$ 等. Van Hoesel 等人 ${ }^{[16]}$ 认为, 支持陨石爆炸和由此引起大面积森林 大火和大型动物突然灭绝的证据都已经基本被否定或质 疑, 而且, 即使有撞击作用发生, 不同地点沉积物记录的 时间差异也不支持是由单一撞击事件所致.

那么, 本项成果对解决上述争议有何贡献呢? 从论文 提供的研究结果来看, 笔者认为并没有提供更多诊断性的 新证据来支持 Hiawatha 撞击诱发了新仙女木事件. 首先, 原文作者没有获得这次撞击事件的准确时间, 仅仅依据基
底冰川的扰动是不能确定其形成年龄的, 况且撞击事件会 彻底摧毁和融化撞击点的冰层, 而不仅仅是扰动. 作者将 该撞击事件的时间大致推测为更新世，也还需要更多直接 证据去支持. 值得注意的是, 如果这次事件形成于 13000 年 左右, 那么所产生的撞击溅射物应该被保存在周边第四纪 沉积物中, 尤其是冰芯中. 然而, 格陵兰岛其他地方的冰 芯记录了过去 10 万年的信息, 却没有发现任何撞击碎片的 迹象. 其次, 对本次撞击事件的环境与生态影响评估都尚 未进行. 因此, 目前还没有找到二者存在因果关系的关键 证据.

尽管 Science 似乎有意将这次撞击事件的时间与新仙 女木事件进行关联, 并以“Ice age impact”为题对该成果进行 了评述 (https://vis.sciencemag.org/breakthrough2018/finalists/ \#cell-development), 但是该项研究的成果尚不足以证明二 者存在必然联系. 如果要继续查证该撞击事件与新仙女木 事件之间的关系，以下工作值得重点关注：(1) 确定 Hiawatha 撞击事件发生的时间; (2) 确定撞击溅射物的分 布区域, 评估气候环境影响强度和范围; (3) 开展与北美及 其他地区新仙女木事件相关地质记录的对比研究, 确定其 因果关系; (4) 模拟本次撞击过程及其气候环境效应, 评估 导致新仙女木事件的可能性等.

在地球的形成和后期演化历史中，撞击作用一直扮演 着重要的角色, 因此备受公众和科学界所关注. 迄今为止, 地球表面被证实的撞击坑有 197 个, 其中, 南美洲 13 个、北 美洲 62 个、非洲 20 个、欧洲 43 个、大洋洲 28 个、亚洲 31 个(其中中国境内仅有一个) $)^{[17]}(\mathrm{http}: / / \mathrm{www}$.meteorimpactonearth.com/meteorite.html). Hiawatha 撞击坑的发现, 提供了一个新的、形态保存最好的地球大型复杂撞击坑范 例, 为开展类地天体撞击作用研究提供了极好的对照样本. 考虑到撞击作用本身的重要性及其对气候和生态环境的 影响, 撞击坑的寻找和确认是一项十分重要的工作, 在此 基础上的深人研究可以帮助回答地球历史中的很多存疑 问题.

致谢国家自然科学基金(41772050)资助.

\section{推葆阅读文献}

1 Kjær K H, Larsen N K, Binder T, et al. A large impact crater beneath Hiawatha Glacier in northwest Greenland. Sci Adv, 2018, 4: eaar8173

2 Stöffler D, Langenhorst F. Shock metamorphism of quartz in nature and experiment: I. Basic observation and theory. Meteoritics, 1994, 29: $155-181$

3 Ferrière L, Osinski G R. Shock metamorphism. In: Osinski G R, Pierazzo E, eds. Impact Cratering: Processes and Products. New Jersey: John Wiley \& Sons, 2012. 106-124

4 Carlson A E. The younger Dryas climate event. In: Elias S A, ed. The Encyclopedia of Quaternary Science. Amsterdam: Elsevier, 2013, 3: $126-134$ 
5 Liu D B. Recent progress on studies of the spatial structure and dynamics for the Younger Dryas Event (in Chinese). Geol Rev, 2012, 58: 341-349 [刘殿兵. 新仙女木(YD)事件区域特征及动力机制研究新进展. 地质论评, 2012, 58: 341-349]

6 Ding X D, Zheng L W, Gao S J. A review on the Younger Dryas Event (in Chinese). Adv Earth Sci, 2014, 29: 1095-1109 [丁晓东, 郑立 伟，高树基. 新仙女木事件研究进展. 地球科学进展, 2014, 29: 1095-1109]

7 Firestone R B, West A, Kennet J P, et al. Evidence for an extraterrestrial impact 12900 years ago that contributed to the megafaunal extinctions and the Younger Dryas cooling. Proc Natl Acad Sci USA, 2007, 104: 16016-16021

8 Kennett D J, Kennett J, West A, et al. Nanodiamonds in the Younger Dryas boundary sediment layer. Science, 2009, 323: 94

9 Bunch T E, Hermes R E, Moore A M, et al. Very high-temperature impact melt products as evidence for cosmic airbursts and impacts 12,900 years ago. Proc Natl Acad Sci USA, 2012, 109: E1903-E1912

10 Pinter N, Scott A C, Daulton T L, et al. The Younger Dryas impact hypothesis: A requiem. Earth-Sci Rev, 2011, 106: 247-264

11 Boslough M, Nicoll K, Holliday V, et al. Arguments and evidence against a Younger Dryas impact event. Geophys Monogr Ser, 2012, 198: $13-26$

12 Scott A C, Pinter N, Collinson M E, et al. Fungus, not comet or catastrophe, accounts for carbonaceous spherules in the Younger Dryas "impact layer". Geophys Res Lett, 2010, 37: L14302

13 Surovell T A, Holliday V T, Gingerich J A, et al. An independent evaluation of the Younger Dryas extraterrestrial impact hypothesis. Proc Natl Acad Sci USA, 2009, 106: 18155-18158

14 Daulton T L, Pinter N, Scott A C. No evidence of nanodiamonds in Younger-Dryas sediments to support an impact event. Proc Natl Acad Sci USA, 2010, 107: 16043-16047

15 Paquay F S, Goderis S, Ravizza G, et al. Absence of geochemical evidence for an impact event at the Bolling-Allerod/Younger Dryas transition. Proc Natl Acad Sci USA, 2009, 106: 21505-21510

16 van Hoesel A, Hoek W Z, Gillian M P, et al. The Younger Dryas impact hypothesis: A critical review. Quat Sci Rev, 2014, 83: 95-114

17 Chen M, Xiao W S, Xie X D, et al. Xiuyan crater, China: Impact origin confirmed. Chin Sci Bull, 2009, 55: 1777-1781 [陈鸣, 肖万生, 谢先德，等. 岫岩陨石撞击坑的证实. 科学通报, 2009, 22: 3507-3511] 


\title{
Did the Hiawatha impact cause the Younger Dryas Event?
}

\author{
Long $\mathrm{Xiao}^{1,2}$ \\ ${ }^{1}$ School of Earth Sciences, China University of Geosciences, Wuhan 430074, China; \\ ${ }^{2}$ Center for Excellence in Comparative Planetology, Chinese Academy of Sciences, Hefei 230026, China \\ E-mail: longxiao@cug.edu.cn
}

Large impact events could cause huge environmental changes and ecological disasters on Earth. Therefore, the possibility of impact events is always considered as a potential cause of sudden climatic, environmental and ecological hazards. Vice versa, a large impact event can also be used to assess its impact on the environmental and ecological systems. In 2018, the Kjær team discovered a new $31 \mathrm{~km}$ diameter impact crater under the Greenland ice sheet. On the basis of regional airbone radar sounding studies, the Kjær team identified a circular depression with small peaks in the center underneath the northwest Greenland Ice Sheet. They then carried out ground-based field studies of the deglaciated forland deposits and found shocked quartz and some impact-related grains. These pieces of evidence provided compelling evidence that the depression under the ice was an impact crater (now named Hiawatha). The Hiawatha crater is now the best morphologically preserved large complex crater on Earth and it has been listed as one of the breakthrough discoveries of the year 2018 by Science. It has attracted significant attention because it's located in Greenland and its potential link with the Younger Dryas Event in the last ice age.

The Younger Dryas Event is one of the most significant environmental and ecological event in the Quaternary era and the trigger for this event has been debated for a long time. According to the impact hypothesis, one or more extraterrestrial objects hit (or exploded over) the Laurentide Ice Sheet about 12900 years ago and caused extensive wildfires, megafaunal extinctions and changes in the human population. Despite much criticism initially leveled at the impact hypothesis, the controversy continues to this day and new evidence, both in favor and against the hypothesis, continues to be published. The newly discovered Hiawatha impact crater might be one more piece of evidence supporting the impact hypothesis as the trigger of the Younger Dryas Event.

However, due to the lack of solid evidence supporting both a temporal correlation and a causality, the available data reported in this study could not prove that there is an unequivical causal relationship between the two events. To prove the cause and effect link between these two events, additional studies should be carried out, including: (1) To determine the time of the Hiawatha impact event; (2) to determine the distribution of Hiawatha impact ejecta and assess its environmental and ecological impacts; (3) to conduct comparative study of geological records related to the Younger Dryas Event in North America and other regions, and assess their causalities; and (4) to simulate the impact process and its climatic and environmental effects, and evaluate the possibility for causing the Younger Dryas Event and its related geologic record.

In summary, the discovery of the Hiawatha crater provides an excellent frame of reference for the study of impact craters on extraterrestrial bodies. Given the importance of the impact itself and its potentially very significant effects on climate and ecological environment, the discovery and analysis underline the importance of the search for and identification of impact craters on Earth, and assessment of their potentially global geological, environmental and biological effects throughout Earth history.

Hiawatha impact crater, Younger Dryas Event, last ice age, impact event, ecological disaster doi: 10.1360/N972019-00339 